\title{
INFLUENCE OF SUSTAINABLE INVOLVEMENT ON INTENT AND SOCIALLY RESPONSIBLE BEHAVIOR OF TOURISTS: CASE OF HOTELS IN THE RURAL DISTRICT OF ASNI
}

Youssef MAKLOUL, National School of Trade and Management of Marrakech, Cadi Ayyad University, Marrakeche, Morocco, y.makloul@uca.ma (corresponding author)

Jaouad CHAABT, Faculty of Legal, Economic and Social Sciences of Marrakech, Cadi Ayyad University, Marrakeche, Morocco, chaabt.jaouad@gmail.com

Rasa PRANSKUNIENE, Vytautas Magnus University, K. Donelaičio g. 58, LT-44248 Kaunas, Lithuania. rasa.pranskuniene@ @du.lt

\begin{abstract}
Awareness of the requirements of sustainable development has become increasingly important in terms of responsible consumption, respect for the environment and promotion of local economies. The purpose of this research is to examine the impact of sustainable involvement and buying intentionof tourists on their socially responsible behavior. An empirical study was conducted with a sample of 113 tourists in Morocco. Validation of hypotheses through bi-varied analysis shows that sustainable involvement and intention have a positive impact on socially responsible behavior. In addition, the age, gender and marital status variables have a significant moderating effect on causality links between groups.
\end{abstract}

Keywords: intentionto responsible consumption, social engagement of tourists, socially responsible behavior sustainable involvement.

\section{INTRODUCTION}

It is commonly known that tourism is one of the fastest growing industries in the world. Tourism at its best has positive economic impacts on target area (Törn-Laapio, 2019). Tourism contributes significantly to the creation of wealth and the reduction of unemployment and poverty with a global tourism demand representing about $12 \%$ of GDP. The sector is also an excellent provider of jobs with 505,000 direct jobs that account for almost 5\% of employment in the entire economy. The tourism sector occupies an important place in the Moroccan economy. It is increasingly viewed by senior management as a strategic sector to accompany economic development. But what about the costs for the environment and the social as well as for sustainable development?

The development of sustainable tourism offers innovative discoveries with the involvement of the local population and preservation of the environment and seems to be really sensible today to be able to respond to real development challenges in Morocco. Today Morocco is in search of sustainability which is at the crossroads of a triple concern: economic, social and environmental. The follow-up of economic development has become a priority, the search for greater social justice, and lastly, the concern to protect and renew natural resources that are not indefinitely extensible. In recent years, we live with a global awareness where the environment and the social are major themes of development strategies.Hence the choice of our theme -the impact of perceived quality on socially responsible behavior, CSR is a dimension of perceived predictive quality of customer/customer satisfaction utilities(Saidi et al., 2016). The concept sustainable development applies to tourism. Thus, the different branches of international tourism are mobilized to respect the principles of sustainable development, thus introduce the notions of management and environmental and social audits, implement codes of good practice, work on quality labels that affect the choice of destinations, promote sustainable tourism including sustainable tourism as a lever for sustainable development.

Responsible tourism practices on a significant positive relationship with the destination sustainability and community satisfaction with particular areas of life. the sustainability dimensions of the destination are corresponding positive quality of life functions of the local residents' domains. It has been found that responsible tourism practices are a predictor of life satisfaction. In addition, the mediating role of destination sustainability and the quality of life of residents requires increased attention to creating sustainable livelihoods (Sariskumar et al., 2018). The effect of responsible behavior of tourist on the choice of destination is positive (Zgolli et al., 2018). According to UNESCO (2002) sustainable tourism means "any form of development, development or tourist activity that respects and preserves natural, cultural and social resources in the long term and contributes in a positive and equitable manner to the economic development and development of individuals. who live, work or stay in these spaces". The concept of sustainable tourism encourages placing man and the environment at the center of any reflection on the development strategies of tourism activity. Adopting sustainable tourism also means first and foremost affirming the political will to control its development by responding to the different needs of the actors living in the area concerned. Morocco can most likely benefit from tourism for its development not only economic but sustainable.Today tourism,

Copyright (C) 2019 The Authors. Published by Vytautas Magnus University. This is an open-access article distributed under the terms of the Creative Commons Attribution License (CC-BY 4.0), which permits unrestricted use, distribution, and reproduction in any medium, provided the original author and source are credited. 
which is a national priority in Morocco, can only become a "winning strategy", if the option "Sustainable Tourism" is chosen and pursued widely and by all. The whole strategy that manages investments, professions and promotion must be based on a sustainable system approach adapted to the realities. Prices and the establishment of a quality label must lead to the best quality/price ratio, For all branches of tourism, regular monitoring, monitoring and control must be put in place quickly. Previous work in marketing on green tourist consumption began in the 1970s. To find concrete solutions on the ground, several attempts were made by practitioners to convince tourists to follow active and responsible behavior through consumption of ecological or green tourism products. A socially responsible tourist is an individual who behaves in a consistent manner while conserving the ecosystem (Kinnear et al., 1974). It is a socially conscious tourist who refers to his purchasing power in order to achieve social change (Webster, 1975). Most previous research has focused on explaining socially responsible attitude and behavior at a broad level, dealing with the ecological environment as a whole. Similarly, few studies have been conducted to examine the relationship between the triad of "involvement, intent, behavior" in the field of green marketing.Nowadays is very important to speak about transition from a "passive tourist" to the "active and responsible". The individual is no longer simple consumer but gives a responsible dimension to consumption. We talk about responsibility as "being part of a whole". In this group, everyone has rights and duties. Responsible consumption therefore allows an awareness of the consequences of each on the public sphere, which has now become sensitive and constrained by a set of effects, so to consume responsibly is to choose an alternative mode of consumption to minimize or improve economic, social and environmental impacts around the world.

The development of sustainable tourism, which offers innovative discoveries with the involvement of the local population and preservation of the environment, seems to be very judicious and able to respond to real challenges of sustainable development Morocco.

This research aims to identify the effect of consumer commitment to the consumption of responsible tourism products on its intent and responsible purchasing behavior.

The objectives pursued in this article are therefore: to what extent does the social commitment of tourists influence socially responsible behavior?Does the social commitment of the tourist have a significant effect on socially responsible behavior? What is the moderating role of some sociodemographic variables in the causal model?

\section{CONCEPTUAL FRAMEWORK FOR RESEARCH}

This work presents a review of the literature and through this review, we found that we have work that focuses on the implication and their impact on the intention and possibly on the responsible consumption. While our objective is to present a review of the literature with the design of a theoretical model.

Concept and measure of Tourist Social Commitment. The concept of social engagement: in social science fields, the concept of commitment underpins an injunction to act for the community. In this perspective, the work of Gagnon et al. $(2004,50)$ suggest that social engagement today is organized around an ideal, rather than conformity to inherited statuses and roles, and that the essential issue is that of building research of self in and through the relationship to the other. Several definitions of social engagement have been proposed in previous work (Witkowski and Reddy, 2010). However, Prohaska et al. (2012) pointed out that the proposed definitions are not precise enough and that the term is often confused with similar concepts such as "social capital" (resources available through social ties in communities) and "civic engagement" (which refers to political activity, belonging and volunteering in civil society organizations). According to these authors, social engagement is defined in this work as the participation of a person in an activity of exchange on social concerns, consisting in giving or receiving something from other people with whom it is interacting without any external constraint. This definition highlights the "internalist" dimension of social commitment that must result from an internal conviction linked to a social ideal and not to an external constraint (Gagnon et al., 2004, 50). Social engagement is therefore part of the specific action (passive or committed) of an individual (Witkowski and Reddy, 2010).

Table 1. Scales of measurement of the social commitment of the tourist

\begin{tabular}{|c|l|}
\hline $\begin{array}{c}\text { Scale adapted } \\
\text { from Vivek } \\
\text { (2009). }\end{array}$ & I am excited about helping society \\
\cline { 2 - 2 } & I am sensitive to the concerns of society \\
\cline { 2 - 3 } & I am not attentive to the fate of others \\
\cline { 2 - 3 } & I am passionate about sharing new societal experiences \\
\cline { 2 - 3 } & I love to spend my free time with disadvantaged populations \\
\cline { 2 - 3 } & I like to learn more about phenomena that affect society \\
\cline { 2 - 3 } & Level of social engagement in responsible tourism: \\
\hline
\end{tabular}

This variable is measured by a 5-point scale, starting with 1 . Very low commitment to 5 . Very strong commitment.

Concept and measurement of involvement in responsible tourism. According to Laurent and Kapferer (1986), Valette-Florence (1989) and Sabadie (1999), the concept of implication appeared in social psychology with Sherif and Cantril in 1947. Work on consumer involvement in marketing is a major concern for many researchers and practitioners who have developed this concept in the study of consumer behavior Costley (1988), Involvement is an "unobservable state that reflects the interest, excitement or emotional attachment of an individual evoked by a given product" (Bloch,1981). The emergence of this concept is attributed to the high personal importance of an act of purchase by the consumer (Zaichkowsky, 1985). Miled-Cherif (2001), considers that "the implication is based on the intensity of the relation between the product, the needs and the values of the individual". In addition, Houston and Rothschild (1978) distinguish three types of implications: situational involvement, long-term involvement and response implication. As part of our research, we will consider the temporal aspect of the implication. In other words, we will study sustainable 
involvement, given its importance emphasized by marketing researchers in the study of consumer behavior. According to Bloch (1982), sustainable involvement translates into long-term individual interest and attachment to the product. In addition, sustainable involvement is seen as a stable and permanent state of the consumer towards a product or brand.

Involvement in responsible tourism. This concept of involvement has had various applications in the context of marketing (Vivek, 2009). Based on the work of Rothschild (1984), involvement in responsible tourism is defined in this work as an observable state of motivation, excitement and interest in the sustainability of tourism.

In contrast to the notion of social engagement (action-oriented), involvement is considered in this research as a concept that reflects a state of mind (Smith and Godbey, 1991). In the context of tourism, several works have established the link between level of involvement and other concepts related to tourism activity such as respect for nature (Jamrozy et al., 1996), attachment to the place (Hwang et al., 2005), choice of destinations (Clements and Josiam, 1995) or the lived experience (Caruana et al., 2014).

Scales of measurement of involvement in responsible tourism.In the literature, the implication was implemented according to three main approaches: multi-item approach, single-item approach and approach according to involvement profiles (Valette-Florence, 1989).However, previous work on tourism has not measured involvement in responsible tourism. Therefore, we used a single indicator to measure the level of involvement in responsible tourism (from 1. Very low involvement to 5. Very strong involvement) taking into account the definition of this concept. An observable state of motivation, excitement and interest in the sustainability of tourism (adapted from Rothschild, 1984).

Concept and measurement of the intention of responsible consumption. The intention to purchase according to Lehu (2004), is the "disposition of a consumer who declares himself favorable to the purchase of a good or a service". Taylor and Todd (1995) have studied the importance of consumer buying intent in reducing household waste. They find that perceived behavioral intent and control positively influences the behavior of responsible drinking. Research was negatively associated with consumer buying intent in favor of sustainable consumption. In addition, the negative relationship was mediated by consumer attitudes toward sustainable consumption, subjective norms, and perceived behavioral control(Yang et al., 2018).

Table 2. Scales of measurement of responsible consumption intention

\begin{tabular}{|l|l|}
\multirow{3}{*}{$\begin{array}{c}\text { Scale adapted } \\
\text { from Binani }\end{array}$} & I keep myself informed about the experiences of others on sustainable and responsible tourism. \\
\cline { 2 - 3 } & I think sustainable and responsible tourism designs the best tourist offers. \\
\cline { 2 - 3 } & Sustainable and responsible tourism is a remarkable, traditional and cultural experience. \\
\cline { 2 - 3 } & $\begin{array}{l}\text { I think that sustainable and responsible tourism represents several cultural specificities, geographic and } \\
\text { solidarity relationships. }\end{array}$ \\
\cline { 2 - 3 } & I do not like mass tourism. \\
\cline { 2 - 3 } & I have a total trust in sustainable and responsible tourism. \\
\cline { 2 - 3 } & I am happy when I consume a sustainable tourism product. \\
\cline { 2 - 3 } & I am happy when I participate in local development. \\
\hline & I feel pleasure to be a socially responsible consumer. \\
\cline { 2 - 3 } & I feel annoyed when people criticize sustainable and responsible tourism. \\
\cline { 2 - 3 } & I prefer to spend my stay in green hotels. \\
\cline { 2 - 3 } & I recommend sustainable and responsible tourism to those around me. \\
\cline { 2 - 3 } & $\begin{array}{l}\text { I actively participate in comments on social networks dedicated to fans of sustainable and responsible } \\
\text { tourism. }\end{array}$ \\
\hline
\end{tabular}

This variable is measured by a 5-point scale, starting from 1 Disagree to 5 Completely agree.

Concept and measurement of the intention of responsible consumption. The responsible behavior of the tourist: based on the work of Gonzalez et al. (2009), where the responsible behavior of the tourist is defined as the consideration of social and environmental concerns in the choice of tourism. Today, we speak of responsible behavior as part of an extended approach to the social dimension (Lee et al., 2013), in line with the work of Brundtland (1987). In the French context, Francois-Lecompte and Prim-Allaz (2009)proposed a typology of tourists by identifying two segments (among five) that can be described as responsible tourists ("neo-sustainable" and "sustainable adventure"). By synthesizing previous work, Lee et al. (2013) distinguish six ways for the tourist to behave responsibly: civil, educational, financial, legal, physical or persuasive actions. However, the work of Dolnicar (2010) emphasize the importance of financial, physical and social actions in the responsible behavior of tourists. They make it possible to offset the ecological footprint of tourism (financial actions), but also to forge stronger links between tourists and residents of the areas visited (physical and social actions), environmental responsibility, subjective norm, and attitude towards sustainable consumption as key predictors of consumers' sustainable consumption intention(Joshi et al., 2019).

Table 3. Scales of measurement of socially responsible behavior

\begin{tabular}{|c|c|}
\hline \multirow{6}{*}{$\begin{array}{l}\text { Scale adapted } \\
\text { from } \\
\text { Lee et al. (2013) }\end{array}$} & I agree to invest in local sustainable tourism projects \\
\hline & I am ready to devote my time and energy to setting up sustainable tourism projects \\
\hline & I agree to pay more to offset my ecological footprint \\
\hline & I want to spend my money on the territory visited in order to benefit the local population \\
\hline & I pay more attention to the resources of the visited countries \\
\hline & Level of socially responsible behavior: \\
\hline
\end{tabular}

This variable is measured by a 5-point scale, starting from 1 - disagree to 5 - completely agree.

Theories mobilized. In this work, we will use the conceptual framework of reasoned action theory, planned behavior, behavioral theory, and social engagement theory. Our research will be a further step in theoretically arguing 
that attitude derives from beliefs and available information. In this case, the conduct or the behavior is voluntary, it depends solely on a choice, and this same choice belongs to the good or the inferior appreciation of the consequences depending on the realization of the action. According to the theory of reasoned action, behavior is impacted by individual behavioral intentions, which are determined by attitudes to that behavior, as well as subjective norms. This theory explains behavior through behavioral intentions (Fishbein and Ajzen, 1975). The theory of reasoned action reveals that attitude is the result of beliefs and existing information. Indeed, the behavior is voluntary, it stems just from a choice, which itself depends on the good or the bad control of the consequences of the realization of the action. Indeed, planned behavior allows one to explain, modify and predict the social behavior of individuals from the knowledge of attitude. This requires that behavior be part of the behavioral intention which itself depends on the attitude towards the behavior and the subjective norm.. The theory of planned behavior postulates that social behavior is excellently voluntary. According to the authors, any behavior generates a choice based on deliberation (Ajzen and Fishbein, 1980); that is to say, before adopting a behavior, the individual thinks or reasons. In other words, he takes into account all the information he possesses, he appreciates the consequences and he also examines the implications of his act. So social conduct is seen as the result of reasoned, planned and controlled decision-making.

In contrast, perceived behavioral control in the theory of planned behavior (Ajzen, 1987) is defined as the ease or difficulty of performing a behavior. In other words, the individual may no longer be in a rhythm of examining his behavior, which implies that the notion of perceived behavioral control proposes that the individual uses his previous experience to prevent and therefore avoid future difficulties. Fishbein's behaviourist theory is based on belief-based attitude, which refers to perceived probability when there is an association between attitude and attribute. However, when there is a satisfaction towards the object which is the tourist service, one will have at the end a score of attitude vis-à-vis the object (tourist service).

The theory of social engagement in the fields of social sciences, the concept of commitment underlies an injunction to act for the community. In this perspective, the work of Gagnon et al. (2004, 50) Propose that social engagement today is organized around an ideal, rather than conformity to inherited statuses and roles, and that the overriding issue is that of building research of self in and through the relationship to the other. Several definitions of social engagement have been proposed in previous work. However, Prohaska et al. (2012) discovered that the suggested definitions are not precise enough and that the term is often confused with identical concepts such as social capital and civic engagement. social engagement is considered to be the collaboration of a person in an activity of exchange on social concerns, to give or obtain something from other people with whom it is interacting without external constraint. This definition highlights the internalist dimension of social commitment that must result from an internal conviction attached to a social ideal and not to an external constraint. Social commitment is therefore part of the specific action (passive or committed) of a person (Witkowski and Reddy, 2010).

Travel and tour operators (TTOs) have become increasingly and positively engaged in Corporate Social Responsibility (CSR) due to increased consumer awareness and responsible business practices (Baniya et al., 2019). In order to study the direct causal link between tourist's social commitment and the socially responsible behavior of tourists on the one hand. on the other hand, we have constructed a conceptual model schematized in Figure 1.

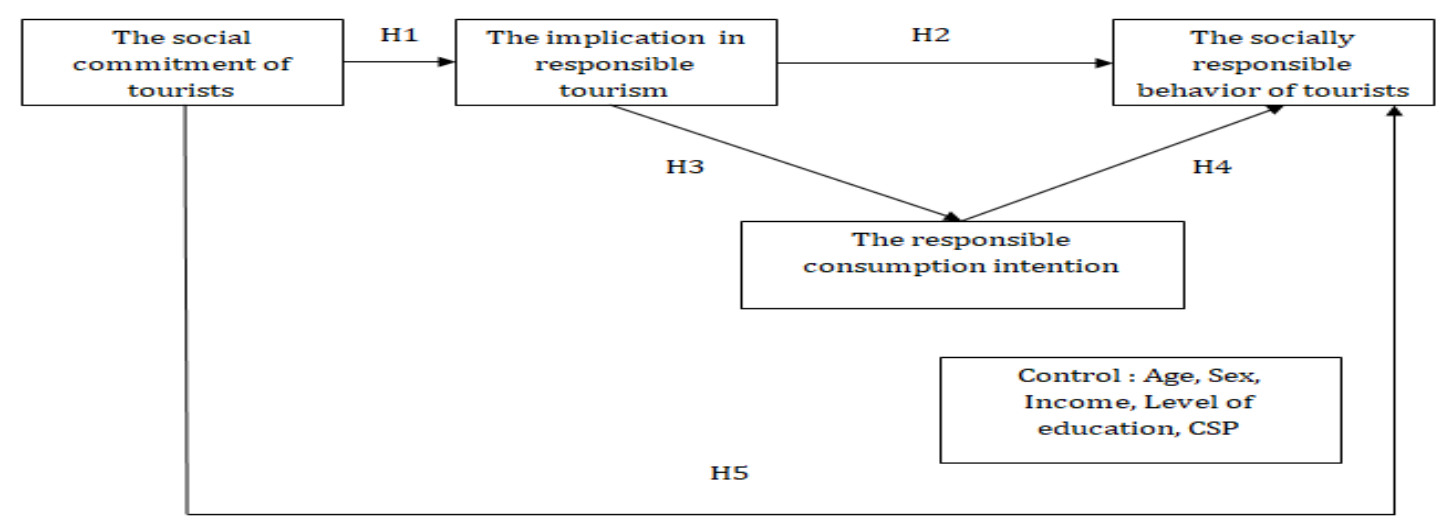

Figure 1. Conceptual framework of social engagement and its impact on socially responsible behavior

Research hypotheses. Based on these contributions, we could present the following assumptions:

H1. The social commitment of tourism positively influences the involvement in responsible tourism.

The social commitment of tourism can impact its involvement in responsible tourism in different ways such as the granting of sums of money (donations) to associations of general interest or the participation in social and civic activities for the benefit of a greener tourism.

H2. Involvement in responsible tourism positively influences the socially responsible behavior of tourists. Involvement influences green buying behavior. And that tourists involved in sustainability develop behaviors. An empirical study was conducted on a sample of 305 individuals in Tunisia. Validation of hypotheses through structural analysis reveals that lasting involvement and intention have a positive effect on the purchasing behavior of individuals. 
In addition, age, gender and marital status variables have a significant moderating impact on the causal links between groups.

H3: Involvement in Responsible Tourism positively influences the intention of responsible consumption. In addition, few empirical studies have validated the impact of ecological intent on purchasing behavior (Chan and Lau, 2000). Based on Ajzen and Fishbein's (1973) 'reasoned action theory', intention is often considered the most important factor and immediate predictor of buying behavior. In addition, Taylor and Todd (1995) have studied the antecedents of household waste reduction behavior (ie, intention, attitude, complexity, efficiency, etc.) as part of the behavioral pattern. waste management, in order to identify the factors that drive people to adopt conscious behaviors towards their environment. Starting from the green marketing work that considers the concern for the environment (PPE) as an attitudinal concept, the work of Chan and Yam (1995), showed that the individual ecological behavior depends on knowledge, sensitivity and of intention. According to the work of (Najar and Zaiem, 2010) sustainable involvement and intention act positively on the ecological or socially responsible behavior, and that the impact of the sustainable implication on the intention of purchase is positive and important. The empirical results of this work coincide with those already developed in previous research. In addition, the examination of the mediating effect shows that the direct effect of the lasting implication on the behavior is more important than that of the indirect effect. However, these results do not exclude the importance of the mediating role of the intent variable in explaining the direct link between sustainable involvement and socially responsible behavior. The results of this work show that the impact of sustainable involvement on intention, as well as the impact of intention on behavior, are stronger in the men's group than in the women's group. In addition, the group of men is characterized by a significant indirect effect mediated by the intention variable and whose value is 0.461 . For the women's group, the mediating effect of the intention is very small compared to the direct link between sustainable involvement and behavior (0.595> 0.196). The results of this work show that the impact of sustainable involvement on intention, as well as the impact of intention on behavior, are more important for single people (Group 1: 18 -24 years) than for the newlyweds (Group 2: 25 -34). Indeed, this research has demonstrated the role of sustainable involvement in the possibility of changing the consumer's intention and buying behavior towards an ecological product. This should help researchers to better understand how the various complex variables of the decision-making process can influence the individual's conscious behavior in adopting socially responsible behavior.From a managerial point of view, gender, age and civil registration moderators seem to be preachers to be taken into consideration when segmenting the market, thus making it possible to better target marketing actions, especially those involving communication, and subsequently a good positioning of economic bulbs in relation to to traditional bulbs.

\section{tourists.}

H4: The intention of responsible consumption positively influences the socially responsible behavior of

According to the theory of planned behavior, behavioral intention is determined by subjective norm and attitude. Attitude can be defined as the favorable or unfavorable estimate of the achievement or non-achievement of behavior (Ajzen and Fishbein, 1980). When green products are more readily available (i.e., high product availability) and/or consumers perceive that their actions of purchasing or using green products can make a positive impact on the environment (i.e., high perceived consumer effectiveness) then consumers with intention to consume green products would be more likely to actually do it. (Nguyen et al., 2019).

H5: Social commitment has a positive influence on the socially responsible behavior of tourists.

Commitment is an important determinant of individual behavior. In fact, individuals engage in associations and adopt eco-responsible behaviors in order to interact on social networks. Although they are interested in the context of organic and ethical consumption Van Doorn (2010). Witkowski and Reddy (2010) notice, that social commitment significantly influences responsible behavior (eg purchase of organic products, recycling, etc.). In the tourism sector, Wei et al. (2013) have established the link between the commitment and the behavior of the tourist in a hotel environment. For them, the behavior of tourists depends on the different interactions at the origin of the commitment of each of the actors of tourism for the achievement of a quality service. The inclusion of variables that collect perceptions of quality service is very important to better understand the individual perception of service quality and move towards sustainable tourism, given the social dimension (Sanzet al., 2019).

Bagri et al. (2009) identified several manifestations of the social engagement of tourists such as participation in local life of the communities visited or giving money to the local community. These essentially social activities reflect a responsible behavior of tourists that translates their social motivations into action to ensure a more responsible and ethical tourism.

\section{METHODOLOGY}

Epistemological choice: we worked with a positivist paradigm (quantitative study, confirmation phase) with a hypothetically-deductive reasoning mode. We administered a face-to-face questionnaire to 113 solidarity tourists from 4 hotels in the Asni rural district (Auberge Tichka Atlas Imli, Kasbab Bab Ourika, Terres d'Amanar Marrakech, Oliveraie de Marigha). This study aims to verify research hypotheses. We administered the questionnaire to solidarity tourists taking part in a solidarity trip with tour operators who took care to respect the environment of the places visited and financing development projects benefiting the local population. At the analysis level, we used SPSS as data processing software to get the result.The Spearman test has been adopted: Spearman's test is appropriate when one tries to analyze the relationship between two ordinal qualitative variables of our conceptual model.

\section{MAIN RESULTS}


The presentation of the results of the quantitative study to answer our initial question to what extent does the social commitment of tourists influence socially responsible behavior? In this regard, our goal is to reveal and interpret the results of the test by referring to our conceptual framework. We have used so many analytical techniques that can be useful for checking the causal links between constructs. As a result, we used SPSS as the data processing software to get the results. The quantitative analysis will be carried out by administering a questionnaire for solidarity tourists participating in a solidarity trip with tour operators financing development projects benefiting the population. Does the social commitment of the tourist have a significant effect on socially responsible behavior? For the test of the hypotheses we proceeded to the test of Spearman, it is the appropriate test when one tries to analyze the Relation between two qualitative variables ordinal.

Results and validation of hypotheses of the causal model.

H1. The social commitment of tourism positively influences the involvement in responsible tourism.

Table 4. The social commitment of tourism the involvement in responsible tourism

\begin{tabular}{|c|c|c|c|c|}
\hline \multicolumn{5}{|c|}{ Correlation } \\
\hline & & & $\begin{array}{c}\text { Social commitment of } \\
\text { tourism }\end{array}$ & $\begin{array}{l}\text { Involvement in responsible } \\
\text { tourism. }\end{array}$ \\
\hline \multirow[t]{4}{*}{$\begin{array}{c}\text { Rho of } \\
\text { Spearman }\end{array}$} & \multirow[t]{2}{*}{$\begin{array}{l}\text { Social commitment of } \\
\text { tourism }\end{array}$} & $\begin{array}{c}\text { Coefficient } \\
\text { ofcorrelation }\end{array}$ & 1.00 & ,903 \\
\hline & & $\begin{array}{l}\text { Sig. (Bilateral) } \\
\mathrm{N}\end{array}$ & 113 & $\begin{array}{l}, 000 \\
113\end{array}$ \\
\hline & \multirow[t]{2}{*}{$\begin{array}{l}\text { involvement in } \\
\text { responsible tourism. }\end{array}$} & $\begin{array}{c}\text { Coefficient } \\
\text { ofCorrelation }\end{array}$ & ,903 & 1.00 \\
\hline & & $\begin{array}{c}\text { Sig. (Bilateral) } \\
\mathrm{N}\end{array}$ & $\begin{array}{c}, 000 \\
113\end{array}$ & 113 \\
\hline
\end{tabular}

Correlation is significant at the 0.05 Level (2-Tailed) $\mathrm{P}<0,05$ Source: Spss, version 22.0

We can say that there is a relation between the two variables, namely the social commitment of tourism level and the involvement in responsible tourism, since the sig is less than 0.005 . Moreover, the two variables are strongly correlated since the coefficient Spearman reaches $90.3 \%$ In other words, the social commitment of tourism has a positive influence on the involvement in responsible tourism.

\section{H2. Involvement in responsible tourism positively influences the socially responsible behavior of tourists}

Table 5. Involvement in responsible tourism the socially responsible behavior of tourists

\begin{tabular}{|c|c|c|c|c|}
\hline \multicolumn{5}{|c|}{ Correlation } \\
\hline & & & $\begin{array}{c}\text { Involvement in responsible } \\
\text { tourism }\end{array}$ & $\begin{array}{c}\text { Socially responsible behavior of } \\
\text { tourists }\end{array}$ \\
\hline \multirow{4}{*}{$\begin{array}{c}\text { Rho of } \\
\text { Spearman }\end{array}$} & \multirow{2}{*}{$\begin{array}{l}\text { Involvement in } \\
\text { responsible } \\
\text { tourism }\end{array}$} & Coefficient ofcorrelation & 1.00 &, 801 \\
\hline & & $\begin{array}{l}\text { Sig. (Bilateral) } \\
\mathrm{N}\end{array}$ & 113 & $\begin{array}{l}001 \\
113\end{array}$ \\
\hline & \multirow{2}{*}{$\begin{array}{c}\text { Socially } \\
\text { responsible } \\
\text { behavior of } \\
\text { tourists }\end{array}$} & $\begin{array}{l}\text { Coefficient of } \\
\text { Correlation }\end{array}$ & ,801 & 1.00 \\
\hline & & $\begin{array}{l}\text { Sig. (Bilateral) } \\
\mathrm{N}\end{array}$ & $\begin{array}{l}, 001 \\
113\end{array}$ & 113 \\
\hline
\end{tabular}

Correlation is significant at the 0.05 Level (2-Tailed) $\mathrm{P}<0,05$ Source: Spss, version 22.0

We can say that there is a relation between the two variables, namely the Socially responsible behavior of tourists level and the involvement in responsible tourism, since the sig is less than 0.005 . Moreover, the two variables are strongly correlated since the coefficient Spearman reaches $80.1 \%$ In other words, Socially responsible behavior of tourists has a positive influence on the involvement in responsible tourism.

\section{H3: Involvement in Responsible Tourism positively influences the intention of responsible consumption.}

Table 6. Involvement in Responsible Tourism- the intention of responsible consumption

\begin{tabular}{|c|c|c|c|c|}
\hline \multicolumn{5}{|c|}{ Correlation } \\
\hline & & & $\begin{array}{c}\text { Involvement in responsible } \\
\text { tourism }\end{array}$ & $\begin{array}{l}\text { Intention of responsible } \\
\text { consumption. }\end{array}$ \\
\hline \multirow[t]{4}{*}{$\begin{array}{l}\text { Rho of } \\
\text { Spearman }\end{array}$} & \multirow{2}{*}{$\begin{array}{l}\text { Involvement } \\
\text { in } \\
\text { responsible } \\
\text { tourism }\end{array}$} & $\begin{array}{l}\text { Coefficient of } \\
\text { Correlation }\end{array}$ & 1.00 & ,786 \\
\hline & & $\begin{array}{l}\text { Sig. (Bilateral) } \\
\mathrm{N}\end{array}$ & 113 & $\begin{array}{l}, 002 \\
113\end{array}$ \\
\hline & \multirow{2}{*}{$\begin{array}{c}\text { Intention of } \\
\text { responsible } \\
\text { consumption. }\end{array}$} & $\begin{array}{c}\text { Coefficient of } \\
\text { Correlation }\end{array}$ & ,786 & 1.00 \\
\hline & & $\begin{array}{l}\text { Sig. (Bilateral) } \\
\qquad \mathrm{N}\end{array}$ & $\begin{array}{l}002 \\
113\end{array}$ & 113 \\
\hline
\end{tabular}

Correlation is significant at the 0.05 Level (2-Tailed) P < 0,05 Source: Spss, version 22.0 
We can say that there is a relation between the two variables, namely the Intention of responsible consumption level and the involvement in responsible tourism, since the sig is less than 0.005 . Moreover, the two variables are strongly correlated since the coefficient Spearman reaches $78.6 \%$ In other words, the Intention of responsible consumption has a positive influence on the involvement in responsible tourism.

\section{H4: The intention of responsible consumption positively influences the socially responsible behavior of tourists.}

Table 7. The intention of responsible consumptionof the socially responsible behavior of tourists

\begin{tabular}{|c|c|c|c|c|}
\hline \multicolumn{5}{|c|}{ Correlation } \\
\hline & & & $\begin{array}{c}\text { Intention of responsible } \\
\text { consumption }\end{array}$ & $\begin{array}{l}\text { Socially responsible behavior of } \\
\text { tourists }\end{array}$ \\
\hline \multirow[t]{4}{*}{$\begin{array}{c}\text { Rho of } \\
\text { Spearman }\end{array}$} & \multirow{2}{*}{$\begin{array}{l}\text { Intention of } \\
\text { responsible } \\
\text { consumption. }\end{array}$} & $\begin{array}{l}\text { Coefficient of } \\
\text { Correlation }\end{array}$ & 1.00 &, 745 \\
\hline & & $\begin{array}{l}\text { Sig. (Bilateral) } \\
\mathrm{N}\end{array}$ & 113 & $\begin{array}{l}, 002 \\
113 \\
\end{array}$ \\
\hline & \multirow[t]{2}{*}{$\begin{array}{l}\text { socially responsible } \\
\text { behavior of tourists. }\end{array}$} & $\begin{array}{c}\text { Coefficient of } \\
\text { Correlation }\end{array}$ & ,745 & 1.00 \\
\hline & & $\begin{array}{l}\text { Sig. (Bilateral) } \\
\text { N }\end{array}$ & $\begin{array}{l}, 002 \\
113\end{array}$ & 113 \\
\hline
\end{tabular}

Correlation is significant at the 0.05 Level (2-Tailed) $\mathrm{P}<0,05$ Source: Spss, version 22.0

We can say that there is a relation between the two variables, namely the Intention of responsible consumption. level and the socially responsible behavior of tourists., since the sig is less than 0.005 . Moreover, the two variables are strongly correlated since the coefficient Spearman reaches $74.5 \%$ In other words, the Intention of responsible consumption.has a positive influence on the socially responsible behavior of tourists.

\section{H5: Social commitment has a positive influence on the socially responsible behavior of tourists.}

Table 8. Social commitment and the socially responsible behavior of tourists

\begin{tabular}{|c|c|c|c|c|}
\hline \multicolumn{5}{|c|}{ Correlation } \\
\hline & & & Social commitment & $\begin{array}{c}\text { Socially responsible behavior of } \\
\text { tourists }\end{array}$ \\
\hline \multirow{4}{*}{$\begin{array}{c}\text { Rho of } \\
\text { Spearman }\end{array}$} & \multirow{2}{*}{$\begin{array}{c}\text { Social } \\
\text { commitment }\end{array}$} & Coefficient of correlation & 1.00 & ,900 \\
\hline & & $\begin{array}{l}\text { Sig. (Bilateral) } \\
\mathrm{N}\end{array}$ & 113 & $\begin{array}{l}000 \\
113\end{array}$ \\
\hline & \multirow{2}{*}{$\begin{array}{c}\text { socially } \\
\text { responsible } \\
\text { behavior of } \\
\text { tourists }\end{array}$} & $\begin{array}{l}\text { Coefficient of } \\
\text { Correlation }\end{array}$ & ,900 & 1.00 \\
\hline & & $\begin{array}{l}\text { Sig. (Bilateral) } \\
\mathrm{N}\end{array}$ & $\begin{array}{l}000 \\
113\end{array}$ & 113 \\
\hline
\end{tabular}

Correlation is significant at the 0.05 Level (2-Tailed) P < 0,05 Source: Spss, version 22.0

We can say that there is a relation between the two variables, namely the Social commitment. level and the socially responsible behavior of tourists, since the sig is less than 0.005 . Moreover, the two variables are strongly correlated since the coefficient Spearman reaches $90 \%$ In other words, the Social commitment.has a positive influence on the socially responsible behavior of tourists. Given that all student's tests are significant at the 5\% threshold, the causal model shows that hypotheses $\mathrm{H} 1, \mathrm{H} 2$ and $\mathrm{H} 3$ are confirmed. What is the moderating role of some sociodemographic variables in the causal model? Results and validation of the hypotheses of the moderating effects.

\section{Moderating role of civil status}

Table 9. Comparison of causality links by marital status

\begin{tabular}{|l|c|c|c|c|}
\cline { 2 - 4 } \multicolumn{1}{l|}{} & \multicolumn{2}{c|}{ Group1: Single } & \multicolumn{2}{c|}{ Group 2 : Married } \\
\cline { 2 - 5 } & $\begin{array}{c}\text { Coefficient } \\
\text { of } \\
\text { Correlation }\end{array}$ & $\begin{array}{c}\text { Sig. } \\
\text { (Bilateral) } \\
\mathrm{N}\end{array}$ & $\begin{array}{c}\text { Coefficient of } \\
\text { Correlation }\end{array}$ & $\begin{array}{c}\text { Sig. (Bilateral) } \\
\mathrm{N}\end{array}$ \\
\hline $\begin{array}{l}\text { The social commitment of tourism positively } \\
\text { influences the involvement in responsible tourism. }\end{array}$ &, 876 &, 000 &, 815 &, 001 \\
\hline $\begin{array}{l}\text { Involvement in responsible tourism positively } \\
\text { influences the socially responsible behavior of } \\
\text { tourists. }\end{array}$ &, 632 &, 003 &, 854 &, 001 \\
\hline $\begin{array}{l}\text { Involvement in Responsible Tourism positively } \\
\text { influences the intention of responsible consumption. }\end{array}$ &, 954 &, 000 &, 832 &, 002 \\
\hline $\begin{array}{l}\text { The intention of responsible consumption positively } \\
\text { influences the socially responsible behavior of } \\
\text { tourists. }\end{array}$ &, 865 &, 000 &, 754 &, 001 \\
\hline $\begin{array}{l}\text { Social commitment has a positive influence on the } \\
\text { socially responsible behavior of tourists. }\end{array}$ &, 765 &, 000 & &, 701 \\
\hline
\end{tabular}

socially responsible behavior of tourists.

Correlation is significant at the 0.05 Level (2-Tailed) $\mathrm{P}<0,05$ Source: Spss, version 22.0 
The table shows that the impact of sustainable involvement on intention, the impact of intention on behavior, the impact of social engagement on socially responsible behavior, and the impact of engagement social on involvement in responsible tourism are more important for singles than for married couples with correlation coefficients of, respectively, $954 /, 865 /, 765 /, 876$. On the other hand, the impact of lasting involvement on behavior is stronger for the bride and groom. Moreover, for the second group represents a direct effect of lasting involvement on the behavior is more important than that of singles $(, 854>, 632)$. In this case, the mediating effect of the intention is important in the group of the newlyweds.

\section{Age-moderating role}

Table 10. Comparison of causality links by age

\begin{tabular}{|c|c|c|c|c|}
\hline & \multicolumn{2}{|c|}{ Group1: 25-34 } & \multicolumn{2}{|c|}{ Group $2: 35$ et +} \\
\hline & $\begin{array}{c}\text { Coefficien } \\
\text { t of } \\
\text { Correlatio } \\
n\end{array}$ & $\begin{array}{c}\text { Sig. } \\
\text { (Bilateral) } \\
\mathrm{N}\end{array}$ & $\begin{array}{c}\text { Coefficien } \\
\text { t of } \\
\text { correlatio } \\
n\end{array}$ & $\begin{array}{c}\text { Sig. } \\
\text { (Bilatera } \\
\text { l) } \\
\mathrm{N}\end{array}$ \\
\hline $\begin{array}{l}\text { The social commitment of tourism positively influences the involvement in } \\
\text { responsible tourism. }\end{array}$ &, 400 & ,076 & ,897 &, 000 \\
\hline $\begin{array}{l}\text { Involvement in responsible tourism positively influences the socially } \\
\text { responsible behavior of tourists. }\end{array}$ & ,324 & ,016 & ,986 & ,000 \\
\hline $\begin{array}{l}\text { Involvement in Responsible Tourism positively influences the intention of } \\
\text { responsible consumption. }\end{array}$ & ,376 & ,026 & ,954 & ,000 \\
\hline $\begin{array}{l}\text { The intention of responsible consumption positively influences the socially } \\
\text { responsible behavior of tourists. }\end{array}$ & ,216 & ,011 & ,832 & ,000 \\
\hline $\begin{array}{l}\text { Social commitment has a positive influence on the socially responsible } \\
\text { behavior of tourists. }\end{array}$ & 234 & ,023 & 864 & ,000 \\
\hline
\end{tabular}

Correlation is significant at the 0.05 Level (2-Tailed) $\mathrm{P}<0,05$ Source: Spss, version 22.0

The comparison between age groups at the table level shows that (Group1: 25-34) is characterized by relatively weak causal links (the values do not exceed 0.4). For group 2, there is a high correlation in all the hypotheses with significant correlation that exceed $80 \%$. So the age variable plays an important role in responsible consumption. A positive correlation means that the two variables tend towards the same direction, the correlation coefficient (r). Its numerical value varies from 1.0 to -1.0. This gives us an indication of the strength of the relationship. In general, $r>0$ indicates a positive relationship, $r<0$ indicates a negative relationship while $r=0$ indicates no relationship (or the variables are independent and unrelated). Here, $r=+1.0$ describes a perfect positive correlation and $r=-1.0$ describes a perfect negative correlation. If the coefficients are closer to +1.0 and -1.0 , the relationship between the variables is stronger.

\section{CONCLUDING INSIGHTS}

The results of our research validated the various hypotheses proposed. Indeed, they have demonstrated the role of social engagement and sustainable involvement in the ability to change consumer intent and consumer behavior towards an ecological tourism product. This should help researchers to better understand how the various complex variables of the decision-making process can influence the conscious behavior of tourists by adopting socially responsible behavior at the 3 levels of the pillar: economic, social and environmental.

In our case, the choice of green hotels by tourists can be an effective solution to minimize energy consumption and promote the economy of the local population.

From a management perspective, moderation variables related to gender, age and marital status appear to be predictors to be taken into account when segmenting the market, which makes it possible to better target marketing actions. especially those involving communication.

The results of our research show that the impact of sustainable engagement on the intent and impact of intention on the behavior and impact of social engagement on socially responsible behavior and the impact of commitment to responsible tourism is more important for single people than for married couples. On the other hand, the impact of a sustainable involvement on the behavior is stronger for the married ones.

The comparison between age groups shows that (group 1:25-34) is characterized by relatively weak causal links (values do not exceed 0.4). For group 2, there is a strong correlation in all hypotheses with a significant correlation greater than $80 \%$. The age variable thus plays an important role in the adoption of socially responsible behavior.

Awareness of the requirements of sustainable tourism is now one of the major concerns of advanced country governments. This awareness has resulted in the continuous awareness of all stakeholders (state, companies, distributors and citizens) and the popularization of more and more environmentally friendly products. This has resulted, among other things, in a series of regulatory measures promoting energy conservation, the promotion of the local economy through local resources and the sharing of cultures.

Finally, the state plays a very important role in the fight against environmental problems and, above all, raises awareness of the environment and generalizes the idea of citizen consumer. Its main role is to encourage tourist establishments to adopt an ecological marketing strategy and tourists to choose eco-friendly hotels. As Font and Lynes 
(2018) notice, tourism may not be subject to the same pressures industries, there remain valuable opportunities to engage these stakeholders in the journey to corporate sustainability and responsibility.

\section{REFERENCES}

1. Ajzen I., Fishbein M. 1980. Understanding attitudes and predicting social behaviour.

2. Ajzen I. 1987. Attitudes, traits, and actions: Dispositional prediction of behavior in personality and social psychology. Advances in expérimental social psychology, Vol. 20, pp. 1- 63. https://doi.org/10.1016/S0065-2601(08)60411-6

3. Ajzen I., Fishbein M. 1973. Attitudinal and normative variables as predictors of specific behavior. Journal of Personality and Social Psychology, Vol. 27(1), 41. https://doi.org/10.1037/h0034440

4. Bagri S., Gupta B., George, B. 2009. Environmental orientation and ecotourism awareness pilgrim adventure tourists and leisure tourists. Preliminar communication, Vol. 57(1), pp. 55-68.

5. Baniya R., Thapa B., Kim M. S. 2019. Corporate Social Responsibility Among Travel and Tour Operators in Nepal. Sustainability, Vol. 11(10), ID 2771. https://doi.org/10.3390/su11102771

6. Binani K. 2013. La perception de la qualité de service rendue par le personnel des institutions financières au Québec. http://archipel.uqam.ca/id/eprint/5340

7. Bloch P. 1982. Involvement beyond the purchase process. Conceptual Issues and empirical investigations, Vol. 9, pp. 413-417.

8. Bloch P.H. 1981. An exploration into the scaling of consumers' involvement with a product class. ACR North American Advances.

9. Borel P. 2001. l'influence de l'implication sur la détermination des catégories de magasins acceptables, Fréquentés et rejetés, Actes du 4ème colloque etienne thil

10. Brundtland G.H., Khalid M., Agnelli S., Al-Athel S. 1987. Our common future. New York.

11. Caruana R, Glozer S, Crane A., Mccabe S. 2014. Tourists' accounts of responsible tourism. Annals of Tourism Research, Vol. 46, pp. 115-129. https://doi.org/10.1016/j.annals.2014.03.006

12. Chan R.Y.K., Yam E. 1995. Green movement in a newly industrializing area: A survey on the attitudes and behaviour of the Hong Kong citizens. Journal of Community \& Applied Social Psychology, Vol. 5(4), pp. $273-284$. https://doi.org/10.1002/casp.2450050405

13. Chan R.Y., Lau L.B. 2000. Antecedents of green purchases: A survey in China. Journal of Consumer Marketing, Vol. 17(4), pp. 338-357. https://doi.org/10.1108/07363760010335358

14. Clements C.J., Josiam B.M. 1995. Role of involvement in the travel decision. Journal of Vacation Marketing, Vol. 1(4), pp. 337348. https://doi.org/10.1177/135676679500100403

15. Costley C. L. 1988. Meta analysis of involvement research. ACR North American Advances.

16. Dolnicar, S. 2010. Identifying tourists with smaller environmental footprints. Journal of Sustainable Tourism, Vol. 18(6), pp. 717-734. https://doi.org/10.1080/09669581003668516

17. Fishbein M, Ajzen I. 1975. Belief, Attitude, Intention and behaviour: An introduction to theory and research. Reading, addisonwesley.

18. Font, X., Lynes, J. 2018. Corporate social responsibility in tourism and hospitality. Journal of Sustainable Tourism, Vol. 6(7), 1027-1042. https://doi.org/10.1080/09669582.2018.1488856

19. François Lecompte A., Prim-Allaz I. 2009. Les français et le tourisme durable: Proposition d'une typologie. Management Avenir, Vol. (9), pp. 308-326. https://doi.org/10.3917/mav.029.0308

20. Gagnon E., Fortin A., Ferland Raymond A.E., Mercier A. 2004. Donner du sens. Trajectoires de benevoles et communautes morales. Lien social et Politiques, Vol. 51, pp. 49-57. https://doi.org/10.7202/008869ar

21. Gonzalez C., Korchia M., Menuet L., Urbain C. 2009. Comment les consommateurs socialement responsables se representent-ils la consommation? Une approche par les associations libres. Recherche et Applications en Marketing, Vol. 24(3), pp. 25-41. https://doi.org/10.1177/076737010902400302

22. Houston M., Rothschild, M.L. 1978. Conceptual and Methodological Perspectives on Involvement, Research Frontiers in Marketing: Dialogues and Directions éd. S. Jain, Chicago, American Marketing Association, pp. 184-187.

23. UNESCO. 2002. Manual of the General Conference, 2002 edition, $188 \mathrm{p}$.

24. Hwang S.N., Lee C., Chen H.J. 2005. The relationship among tourists' involvement, Place attachment andinterpretation satisfaction in taiwan's national parks. Tourism Management, Vol. 26(2), pp. $143-156$. https://doi.org/10.1016/j.tourman.2003.11.006

25. Yang S., Li L., Zhang J. 2018. Understanding consumers' sustainable consumption intention at china's double-11 online shopping festival: An extended theory of planned behavior model. Sustainability, 10(6), 1801. https://doi.org/10.3390/su10061801

26. Jamrozy U, Backman S, Backman K. 1996. Involvement and opinion leadership in tourism. Annals of Tourism Research, Vol. 23(4), pp. 908-924. https://doi.org/10.1016/0160-7383(96)00022-9

27. Joshi, Y., Sangroya, D., Srivastava, A.P., Yadav, M. 2019. Modelling the predictors of young consumers' sustainable consumption intention. International Journal of Nonprofit and Voluntary Sector Marketing, Vol. 24, https://doi.org/10.1002/nvsm.1663

28. Kinnear T.C., Taylor J.R., Sadrudin A. 1974. Ecologically concerned consumers: Who are they? Ecologically concerned consumers can be identified. Journal of Marketing, Vol. 38, pp. 20-24. https://doi.org/10.1177/002224297403800205

29. Lehu J. M. 2004. L'encyclopédie du Marketing, Éditions d'Organisation, Paris, 1e éd, 956 p.

30. Miled-Cherif B. H. 2001. L'implication du consommateur et ses perspectives stratégiques. Recherche et Applications en Marketing, Vol. 16, pp. 66-86. https://doi.org/10.1177/076737010101600105 
31. Najar C., Zaiem I. 2010. Influence de l'implication durable sur l'intention et le comportement d'achat écologique. Revue libanaise de gestion et d'économie, Vol. 3(4), pp.1-35. https://doi.org/10.1016/S1999-7620(10)70020-3

32. Nguyen H.V., Nguyen, C.H., Hoang, T.T. B. 2019. Green consumption: Closing the intention-behavior gap. Sustainable Development, Vol. 27(1), pp. 118-129. https://doi.org/10.1002/sd.1875

33. Prohaska T.R., Anderson L.A., Binstock R.H. 2012. Public Health for an Aging Society. Baltimore, MD: HU Press.

34. Rothschild M. 1984. Perspectives on involvement: Current problems and future directions. ACR North American Advances.

35. Rothschild M.L. 1981. Behavioral learning theory: Its relevance to marketing and promotions. Journal of Marketing, Vol. 45(2), pp. 70-78. https://doi.org/10.1177/002224298104500207

36. Sabadie W. 1999. Implication produit et implication organisationnelle: Distinction, Complémentarité ou intégration?, Actes du 15ème congrès international de l'afm, Strasbourg, pp. 1-25.

37. Saidi C., El Abbadi B. 2016. La RSE comme dimension de la qualité perçue: Proposition d'un modèle des déterminants sociétaux de la qualité perçue prédictifs de la satisfaction dans le contexte des Services Publics à caractère Industriel et Commercial/[CSR as a dimension of perceived quality: A model of societal determinants of perceived quality to predict customer satisfaction in the context of commercial and industrial utilities]. International Journal of Innovation and Applied Studies, 17(3), 838-851.

38. Sanz M.F., Ferrandis E.D., Ferrer J.G. 2019. Service Quality Scales and Tourists with Special Needs: A Systematic Review. Sustainability, Vol. 11(14), pp. 1-12. https://doi.org/10.3390/su11143844

39. Sariskumar N., Bhavan T. 2018. The impact of responsible tourism on destination sustainability and quality of life in passikudah tourism destination. International Journal of Social Science and Economic Research, Vol. 03, Iss. 11.

40. Sherif M., Cantril H. 1947. The psychology of ego-involvements: Social attitudes and identifications. https://doi.org/10.1037/10840-000

41. Smith S, Godbey G. 1991. Leisure, Recreation and tourism. Annals of Tourism Research, Vol. 18(1), pp. 85-100. https://doi.org/10.1016/0160-7383(91)90041-9

42. Taylor S, Todd P. 1995. An integrated model of waste management behavior: A test of household recycling and composting intentions. Environment and Behavior, Vol. 27(5), pp. 603-630. https://doi.org/10.1177/0013916595275001

43. Törn-Laapio,A. 2019. Special Issues in Responsible Tourism. JAMK university of applied sciences.

44. Valette Florence P. 1989. Conceptualisation et mesure de l'implication. Recherche et applications en marketing, Vol. 4, , pp. 5778. https://doi.org/10.1177/076737018900400104

45. Van Doorn J., Lemon K.N., Mittal V., Nass S., Pick D., Pirner P.,Verhoef P.C. 2010. Customer engagement behavior: Theoretical foundations and research directions. Journal of Service Research, Vol. 13(3), pp. $253-266$. https://doi.org/10.1177/1094670510375599

46. Vivek S.D. 2009. A scale of consumer engagement. Phd thesis. University of alabama, Tuscaloosa.

47. Webster J.R., Frederick E. 1975. Determining the characteristics of the socially conscious consumer. Journal of Consumer Research, Vol. 2, p. pp. 188-196. https://doi.org/10.1086/208631

48. Wei W., Miao L., Huang Z.J. 2013. Customer engagement behaviors and hotel responses. International Journal of Hospitality Management, Vol. 33, pp. 316-330. https://doi.org/10.1016/j.ijhm.2012.10.002

49. Witkowski T., Reddy S. 2010. Antecedents of ethical consumption activities in germany and the united states. Australasian Marketing Journal, Vol. 18(1), pp. 8-14. https://doi.org/10.1016/j.ausmj.2009.10.011

50. Zaichkowsky J.L. 1985. Measuring the involvement construct. Journal of Consumer Research, BVol. 12, pp. $341-352$. https://doi.org/10.1086/208520

51. Zgolli, S., Zaiem, I. 2018. The responsible behavior of tourist: The role of personnel factors and public power and effect on the choice of destination. Arab Economic and Business Journal, Vol. 13(2), pp. 168-178. https://doi.org/10.1016/j.aebj.2018.09.004 